\title{
Development of a benthic multimetric index for the Serra da Bocaina bioregion in Southeast Brazil
}

\author{
Baptista, DF. ${ }^{a *}$, Henriques-Oliveira AL. ${ }^{a, b}$, Oliveira, RBS. ${ }^{a}$, Mugnai, R. $^{a}$, \\ Nessimian, $J L^{b}$ and Buss, DF. ${ }^{a}$ \\ ${ }^{a}$ Laboratório de Avaliação e Promoção da Saúde Ambiental - LAPSA, IOC/FIOCRUZ. Av. Brasil 4365, \\ CEP 21045-900 Manguinhos, RJ, Brazil \\ ${ }^{b}$ Laboratório de Entomologia, Departamento de Zoologia, Instituto de Biologia, CCS, UFRJ, Ilha do Fundão, \\ CP 68044, CEP 21970-944 Rio de Janeiro, RJ, Brazil \\ *e-mail:darcilio@ioc.fiocruz.br
}

Received June 19, 2012 - Accepted July 30, 2012 - Distributed August 31, 2013

(With 4 figures)

\begin{abstract}
Brazil faces a challenge to develop biomonitoring tools to be used in water quality assessment programs, but few multimetric indices were developed so far. This study is part of an effort to test and implement programs using benthic macroinvertebrates as bioindicators in Rio de Janeiro State. Our aim was first to test the Multimetric Index for Serra dos Órgãos (SOMI) for a different area - Serra da Bocaina (SB) - in the same ecoregion. We sampled 27 streams of different sizes and altitudes in the SB region. Despite the environmental similarities, results indicated biological differences between reference sites of the two regions. Considering these differences, we decided to develop an index specific for the SB region, the Serra da Bocaina Multimetric Index (MISB). We tested twenty-two metrics for sensitivity to impairment and redundancy, and six metrics were considered valid to integrate the MISB: Family Richness, Trichoptera Richness, \% Coleoptera, \% Diptera, IBE-IOC index, EPT / Chironomidae ratio. A test of the MISB in eleven sites indicated it was more related to land-use and water physico-chemical parameters than with altitude or stream width, being a useful tool for the monitoring and assessment of streams in the bioregion.
\end{abstract}

Keywords: biomonitoring, macroinvertebrates, freshwater ecoregions, watershed management, stream ecology.

\section{Desenvolvimento de um índice multimétrico bentônico para a bioregião da Serra da Bocaina no Sudeste do Brasil}

\section{Resumo}

O Brasil enfrenta o desafio de desenvolver ferramentas de biomonitoramento para serem utilizadas em programas de avaliação da qualidade de águas, porém poucos índices multimétricos foram construídos para esta finalidade. Este estudo faz parte de um esforço para testar e implementar programas de biomonitoramento utilizando macroinvertebrados bentônicos como bioindicadores no Estado do Rio de Janeiro. Nosso objetivo foi primeiro testar se as métricas que compõem o Índice Multimétrico da Serra dos Órgãos (SOMI) eram válidas para serem aplicadas em um área diferente - Serra da Bocaina (SB) - pertencente à mesma ecoregião. Nós amostramos 27 riachos de diferentes tamanhos e altitudes na região da Serra da Bocaina. Apesar das similaridades ambientais, os resultados indicaram haver diferenças entre locais de referencia nas duas regiões. Considerando tais diferenças, nós desenvolvemos um índice específico para região da SB, denominado de Índice Multimétrico da Serra da Bocaina (IMSB). Testamos vinte e duas métricas quanto à sensibilidade e redundância. Seis métricas foram consideradas válidas para integrar o IMSB: Riqueza de Famílias, Riqueza de Trichoptera, \% Coleoptera, \% Diptera, índice IBE-IOC e Taxa EPT / Chironomidae. O teste do IMSB indicou que o índice estava mais relacionado aos parâmetros físicos e químicos da água e ao uso da terra do que com a altitude ou largura dos rios. Assim, consideramos uma ferramenta útil para monitorar e avaliar riachos na bioregião estudada.

Palavras-chave: biomonitoramento, macroinvertebrados, ecoregiões de água doce, manejo de bacia hidrográfica, ecologia de riachos. 


\section{Introduction}

The integrity of aquatic ecosystems can not be analyzed solely based on physical and chemical parameters of the water; it must consider the physical habitat structure, flow and channel modifications, biological alterations, and land-use in the watershed (Karr and Dudley, 1981). Among many tools to assess environmental impairments, biological indicators may provide useful information on the effects of impacts on the ecosystems. Many organisms may be used as bioindicators, and benthic macroinvertebrates are the most commonly used in bioassessment protocols. Macroinvertebrate assemblages may be used to indicate the quality of the environment, being particularly efficient for continuously registering environmental conditions (Johnson et al., 1993; King and Richardson, 2003; Gabriels et al., 2010).

Several programs of biological monitoring of aquatic ecosystems were developed from Kolkwitz and Marsson's (1909) saprobic system - based on the presence of indicative species and their tolerance to pollution - including the Biotic Condition Index (Winget and Mangun, 1979); Biological Monitoring Working Party Score System - BMWP (Armitage, et al., 1983), Indice Biotico Esteso - IBE (Ghetti, 1997), FBI index (Hilsenhoff, 1987, 1988), among others (Metcalfe, 1989). In the 1980s, the multimetric system (Karr et al., 1986; Karr 1991) became popular, especially in the United States (Plafkin et al., 1989; Barbour et al., 1996; Barbour et al., 1999; Gibson et al., 1996; Blocksom, 2003). This bioassessment framework is based on the establishment of reference areas which are compared to impaired sites. Recently, countries of the European Union, following the propositions defined by the European Community Water Framework Directive (EC 2000), adopted multimetric indices based on macroinvertebrates (Böhmer et al., 2004; Buffagni et al., 2004; Hering et al., 2004; Pinto et al., 2004; Vlek et al., 2004) as a primary tool to assess the ecological quality of waters.

In Brazil, research institutes traditionally adapted monometric biotic indices using macroinvertebrates for streams and rivers, specially the BMWP index (Junqueira and Campos, 1998). Recently, there is a great effort to develop and test bioassessment protocols in Brazil using benthic macroinvertebrates (CETESB 2002; Baptista et al., 2007; Mugnai et al., 2008; Buss and Borges, 2008; Moreno et al., 2009, Buss and Vitorino, 2010, Oliveira et al., 2011; Baptista et al., 2011; Ferreira et al., 2011, Couceiro et al., 2012). In Rio de Janeiro State, one multimetric index (Serra dos Órgãos Multimetric Index SOMI; Baptista et al., 2007) was developed to Serra do Mar area. In this study, we developed and tested a Multimetric Index for Serra da Bocaina region (MISB), a different area in the same ecoregion.

\section{Methods}

\subsection{Study area}

Originally, the Atlantic Rainforest biome covered $1,360,000 \mathrm{~km}^{2}$. Today, this is the most populated area in Brazil $-70 \%$ of the population lives in this region - and less than $8 \%$ of the biome preserve its original biotic characteristics (MMA/SBF, 2000). This study included two sections of the Serra do Mar mountain chain in Rio de Janeiro State: Serra dos Órgãos (SO) and Serra da Bocaina (SB) (Figure 1). The SO region covers an area of approximately $12,904 \mathrm{~km}^{2}$, with $200 \mathrm{~km}^{2}$ protected by the Serra dos Órgãos National Park (located between $22^{\circ} 26^{\prime} 58.43$ ' S and 42 $\left.59^{\prime} 08.21^{\prime \prime} \mathrm{W}\right)$. The Park protects forests mainly in high slope areas between 200 and 2,263 m.a.s.1. The climate is tropical super humid, with an annual average temperature of $18{ }^{\circ} \mathrm{C}$ and annual precipitation between 1,250 and $1,500 \mathrm{~mm}$. The $\mathrm{SB}$ region is partially preserved by the Serra da Bocaina National Park, the largest preserved forest fragment in the State (around $1,000 \mathrm{~km}^{2}$, located between and $22^{\circ} 40^{\prime}-23^{\circ} 20^{\prime} \mathrm{S}$ and $44^{\circ} 24^{\prime}-44^{\circ} 54^{\prime} \mathrm{W}$ ), with $60 \%$ of native vegetation and the remainder consisting of a $30-\mathrm{y}$ regenerated (secondary) forest. The climate is classified as temperate super humid with annual precipitation of $1,800 \mathrm{~mm}$. Average temperature is around $16{ }^{\circ} \mathrm{C}$ but with a high variation between lowland areas $\left(36-38{ }^{\circ} \mathrm{C}\right.$, around 200 m.a.s.1. $)$ to upper areas $\left(0-4{ }^{\circ} \mathrm{C}\right.$, with a maximum altitude of 2,132 m.a.s.1.) (Guimarães et al., 2000).

\subsection{Sample collection and analysis}

Benthic samples were collected in 10 sites at $\mathrm{SO}$ region (all reference) and 27 sites at SB region (10 reference, 6 impaired and 11 test sites) during the dry season (June-August 2002 to 2004) using a Surber sampler (900 $\mathrm{cm}^{2}$ area, $185 \mu \mathrm{m}$ mesh). Twelve samples were collected at each site, three of each microhabitat (sediment, stone, pool litter and riffle litter), and pooled as one sample per site. Samples were preserved in the field with

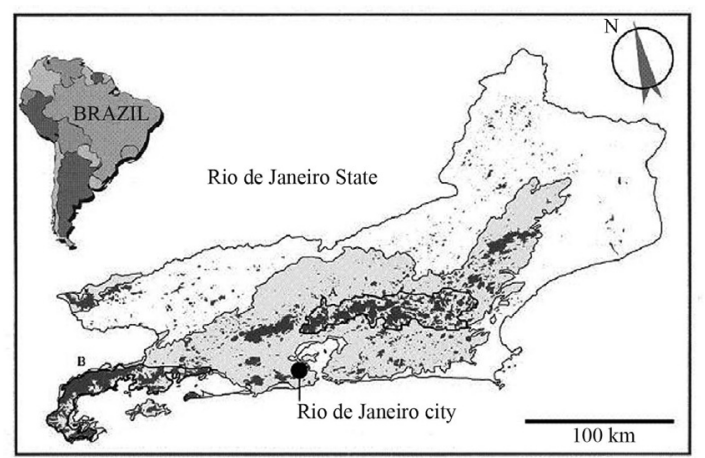

Figure 1 - Map of Rio de Janeiro State. Light grey areas indicate original limits of the Atlantic rainforest and dark grey areas indicate forest remnants. Solid bold line indicates approximate limits of the bioregions of Serra dos Órgãos (A) and Serra da Bocaina (B). 
$80 \%$ ethanol and were fully examined with stereomicroscope in the laboratory. Identification to the lowest possible taxonomic level were performed using the available taxonomic keys (Odonata - Belle, 1992; Carvalho, 1989; Carvalho and Calil, 2000, Carvalho, et al., 2002, Ephemeroptera - Da Silva et al., 2003; Salles et al., 2004; Plecoptera - Olifiers et al., 2004; Hemiptera - Nieser and De Mello, 1997; Trichoptera - Angrisano, 1995, Wiggins, 1996; Coleoptera - Passos et al., 2007; other groups - Merritt and Cummins, 1996). All orders were identified to genus level, except for Diptera, Hemiptera and Lepidoptera, which were identified to family level. For Functional Feeding Groups determination, we used data available from Merritt and Cummins (1996) and Baptista et al. (2006) for Ephemeroptera.

In each sampling site, the Riparian Channel Environment Index (Petersen, 1992) and estimates of mean width of riparian cover were performed visually. The RCE index is calculated based on sixteen environmental parameters such as land-use patterns, stream channel morphology and riparian vegetation. For each parameter a score is given, summed, and the final score is compared to a table to determine one of the five classes of environmental integrity. Also, altitude (using a Garmin GPS76), river mean depth, width, water discharge (flotation method), $\mathrm{pH}$ (LabConte mPA-210p), and water temperature were measured. Water was sampled for further physical and chemical analysis in the laboratory (Conductivity, Total-P, Total-N, NH3-N, Cl- using a spectrophotometer Hach DR2500 and Total Alkalinity using titulometric method - FEEMA, 1979). Stream orders were determined using the Strahler system with 1:50,000 scale maps. The \%Urban and \%Forested areas were determined using satellite images (CBERS-2 High Resolution CCD Camera - at $20 \mathrm{~m}$ spatial resolution, 5 bands) in $200 \mathrm{~m}$ wide buffer zones upstream each sampled sites using the software ArcView 9.1. Range of coordinates of extreme sampled sites was: Serra dos Órgãos $22^{\circ} 27^{\prime} 14$ ' S to $22^{\circ} 15^{\prime} 24^{\prime \prime} \mathrm{S}$; $42^{\circ} 56^{\prime} 59^{\prime \prime} \mathrm{W}$ to $42^{\circ} 08^{\prime} 55^{\prime \prime}$ $\mathrm{W}$; Serra da Bocaina $23^{\circ} 17^{\prime} 26^{\prime \prime} \mathrm{S}$ to $22^{\circ} 50^{\prime} 55^{\prime \prime} \mathrm{S}$; $44^{\circ} 43^{\prime} 54^{\prime \prime} \mathrm{W}$ to $43^{\circ} 59^{\prime} 47^{\prime}$ ' W. Sampling sites varied in altitude (10 to 1,575 m.a.s.1.) and stream order $\left(1^{\text {st }}\right.$ to $\left.5^{\text {th }}\right)$, but were similar regarding substrate composition, being mainly dominated by stones (boulders, cobble and pebble) (Table 1). Sampling through this altitudinal gradient and stream sizes was performed to include these natural variations within the index, allowing a widespread application in the region.

For both river basins, a site was considered as "reference" by meeting all the following criteria: water $\mathrm{pH}$ 6-8; Dissolved Oxygen $\geq 4 \mathrm{mg} / \mathrm{L}$; land use with maximum of $20 \%$ of the basin area urbanized and $\geq 75 \%$ of the upstream basin area forested; width of the riparian range $\geq 15 \mathrm{~m}$; no visible channelization, and a Excellent or Very Good classification according to the RCE index (Petersen, 1992). For the "impaired" condition, any of the following a priori conditions should be met: defores- tation of $\geq 75 \%$ of the upstream area, and Poor classification according to the RCE index.

\subsection{Development of the multimetric index for Serra da Bocaina (MISB)}

Based on the procedures described in Klemm et al. (2003), Baptista et al. (2007) and Baptista et al. (2011) we followed four steps to develop the Multimetric Index for Serra da Bocaina (MISB). First we tested if metrics defined in the SOMI (Family Richness, Ephemeroptera + Plecoptera + Trichoptera (EPT) Richness, \% Coleoptera, $\%$ Diptera, BMWP-CETEC, \% Shredders) could be used for $\mathrm{SB}$ region. We tested if the composition and structure of the benthic assemblage in 10 reference sites at $\mathrm{SO}$ and 10 at SB region were similar and could be treated as the same bioregion (UPGMA Cluster Analysis using BrayCurtis dissimilarity index for quantitative data and Jaccard similarity coefficient for qualitative data; PAST software - Hammer, et al., 2001). Then we calculated each of the 6 metrics used in the SOMI and verified if their values in SB reference sites were within the predicted range for reference conditions. We hypothesized that if the two regions had similar faunal structure and composition, and if the SOMI metric scores were applicable for the SB reference sites, this index could be used or adapted for the SB region. However, since differences were found between the two regions, the second step was to test the sensitivity of 22 metrics to detect differences between 10 reference and 6 impaired sites in the SB region, using Mann-Whitney U tests. Tested metrics were: 6 Richness Metrics - Total taxa, Family taxa, Ephemeroptera taxa, Plecoptera taxa, Trichoptera taxa, Ephemeroptera + Plecoptera + Trichoptera (EPT) taxa; 7 Composition Metrics - \% Coleoptera, \% Ephemeroptera, \% Plecoptera, \% Trichoptera, \% Odonata, \% Diptera and \% EPT; 4 Tolerance Metrics - IBE-IOC, BMWP-CETEC, Baetidae / Ephemeroptera, EPT / Chironomidae; and 5 Trophic Metrics - \% Shredders, \% Collectors, \% Predators, \% Filterers, \% Scrapers. The IBE-IOC (Mugnai et al., 2008) and the BMWP-CETEC (Junqueira and Campos 1998) are biotic indices adapted to Brazil. Metrics that failed to discriminate reference from impaired sites were eliminated. The remaining metrics were evaluated for redundancy using Pearson correlation coefficients. Metrics with a correlation coefficient $r \geq 0$. 8 were considered redundant. In this case, only one metric was included in the final index, often the easier and less timeconsuming to calculate.

The third step was to integrate metrics considered valid in the MISB. The Continuous Scoring Method suggested by Frey (1977) was used to score or standardize the metrics values. Blocksom (2003) recommended it as the best option because it increases the sensitivity and stability of the resulting index. This method was originally used by Minns et al. (1994) in the littoral zone of the Great Lakes. Ganasan and Hughes (1998) and Klemm et al. (2003) used it in stream ecosystems. The scoring method uses the first and third quartile of values from 
Baptista, DF. et al.

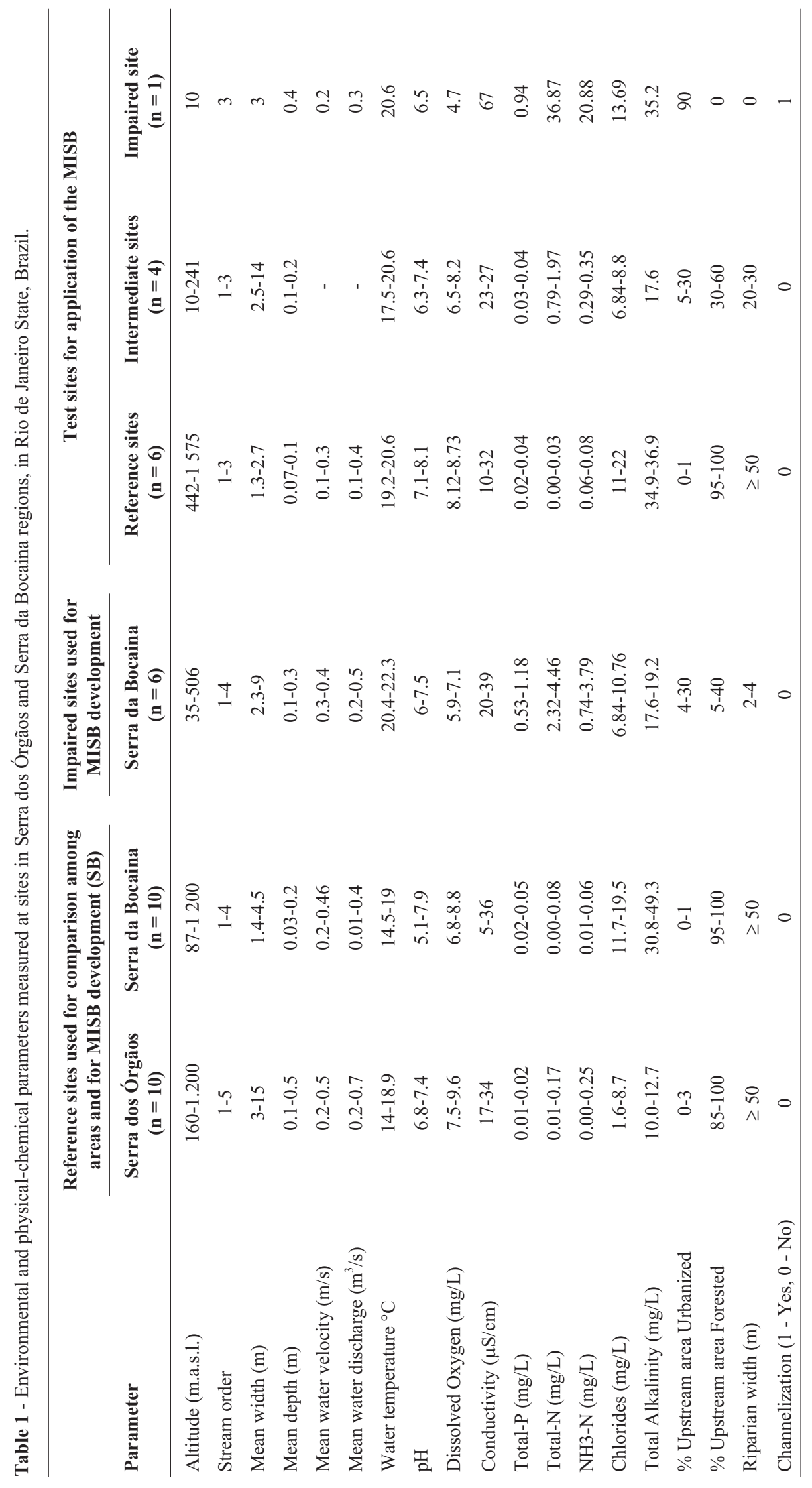


each set of reference or impaired rivers. The scoring procedure is completed using these distribution metrics and two formulae (see below), to determine whether metric values increase or decrease when degradation increases.

The procedure used to apply the index in 11 sites test was achieved in five steps: (1) computing all six core metrics; (2) scoring the metrics using the formula (a) (see below) for metrics that decrease with increasing impairment and formula (b) (see below) for metrics that increase with increasing impairment; (3) applying a simple interpolation to adjust values to a range between $0-10$ (negative values must be considered zero and the highest value must be considered 10); (4) multiplying the values of each one of the metrics times 1.6 (individual weights) in order to obtain values ranging from 0 to $100 ;$ (5) in this last step the values of each metric are summed to obtain a final score for the MISB. This final MISB value that results from the application of the index in each test site falls into one of five quality categories, indicating the ecological integrity of the assessed location.

Formule (a)

Standard metric $=\frac{\text { Metric result }-25 \text { th percentile of impaired sites }}{75 \text { th percentile of reference sites }-25 \text { th percentile of impaired sites }} \times 10$

Formule (b)

Standard metric $=\frac{\text { Metric result }-75 \text { th percentile of impaired sites }}{25 \mathrm{~h} \text { percentile of reference sites }-75 \text { th percentile of impaired sites }} \times 10$

A validation test of the MISB sensitivity was conducted in 11 sites located in the altitudinal gradient, judged to be representative of the degradation gradient. These sites were not used to build the index. The test was performed using a Principal Component Analysis (PCA) of environmental variables. The data matrix was standardized by applying $\left(x_{i}-\bar{x}\right) / \sigma$, where $x_{i}$ is the observed value, $\bar{x}$ is the mean and $\sigma$ is the standard deviation. The assessment of the index was done using a Pearson correlation between the scores of sites in PCA axis 1 and the MISB scores. Analyses were done using BioEstat 2.0 (Ayres et al., 2000).

\section{Results}

Cluster Analyses using Bray-Curtis Dissimilarity and Jaccard index were used to verify the similarity of

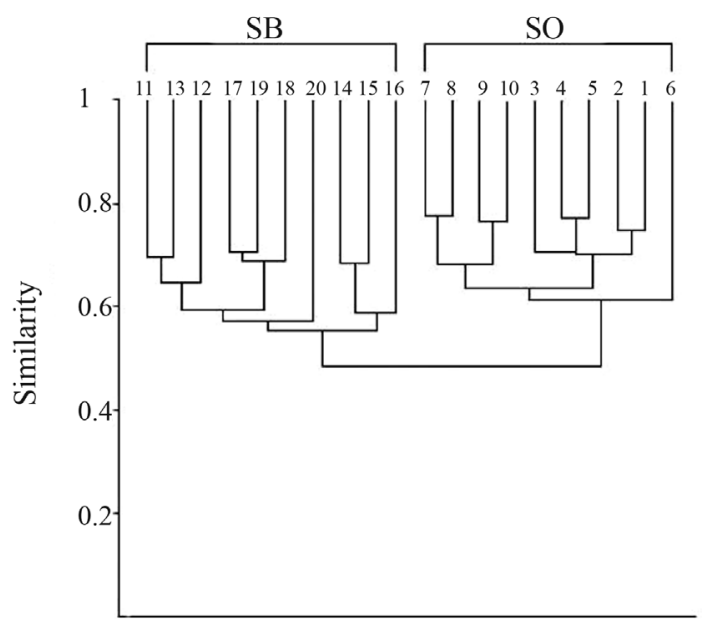

Figure 2 - UPGMA Cluster Analysis using Bray-Curtis dissimilarity index for macroinvertebrate assemblages collected in reference sites in the Serra dos Órgãos (1-10) and Serra da Bocaina (11-20) regions, Rio de Janeiro State, Brazil. Jaccard index had the same results and are not shown for brevity. structure and composition of benthic assemblages of 10 reference sites in Serra dos Órgãos (SO) and 10 in Serra da Bocaina (SB). Results showed sites of the two regions distinct biologically (Figure 2). This pattern may be a result of the higher richness of almost all macroinvertebrate orders found in SB reference sites, totaling a mean of 74 taxa per site (range of 64-90 taxa), while SO sites had a mean of 45 taxa per reference site (39-57 taxa). If we only consider total richness of EPT genera found in the two bioregions (65; with 33 Trichoptera, 25 Ephemeroptera and 7 Plecoptera), SB had 64 genera occurring in this region, while only 42 genera were found in SO sampling sites. Other major difference concerned the shredder functional feeding group: despite the small number of shredder taxa at both regions ( 8 in SB, 6 in SO), their relative abundance was higher in SB (around $10 \%$ of the total, while less than $1 \%$ of the total was usually found in SO sites).

To check if SOMI metric scores for SB sites were compatible with the predicted range for SO reference sites we applied each of the six metrics used in the SOMI for the SB reference sites. Results showed that values of all metrics calculated for SB reference sites were compatible with those expected for reference sites in the SO region, but \%Shredders and EPT richness metric values were much higher than the upper threshold expected for reference sites in SB region, indicating that thresholds should be re-dimensioned if these metrics should be used in the region (Figure 3).

Considering the biological differences between the two regions, we decided to test metrics and to develop an index for the SB region, the Serra da Bocaina Multimetric Index (MISB). So, we tested the sensitiveness of 22 metrics to detect differences between 10 reference and 6 impaired sites in the SB region. Fifteen metrics were able to discriminate these conditions according to the Mann-Whitney U test $(\mathrm{p}<0.05)$ : Total Richness, Family Richness, Ephemeroptera Richness, Plecoptera Richness, Trichoptera Richness, EPT Richness, Ratio EPT/Chironomidae, BMWP-CETEC, IBE-IOC, \% 

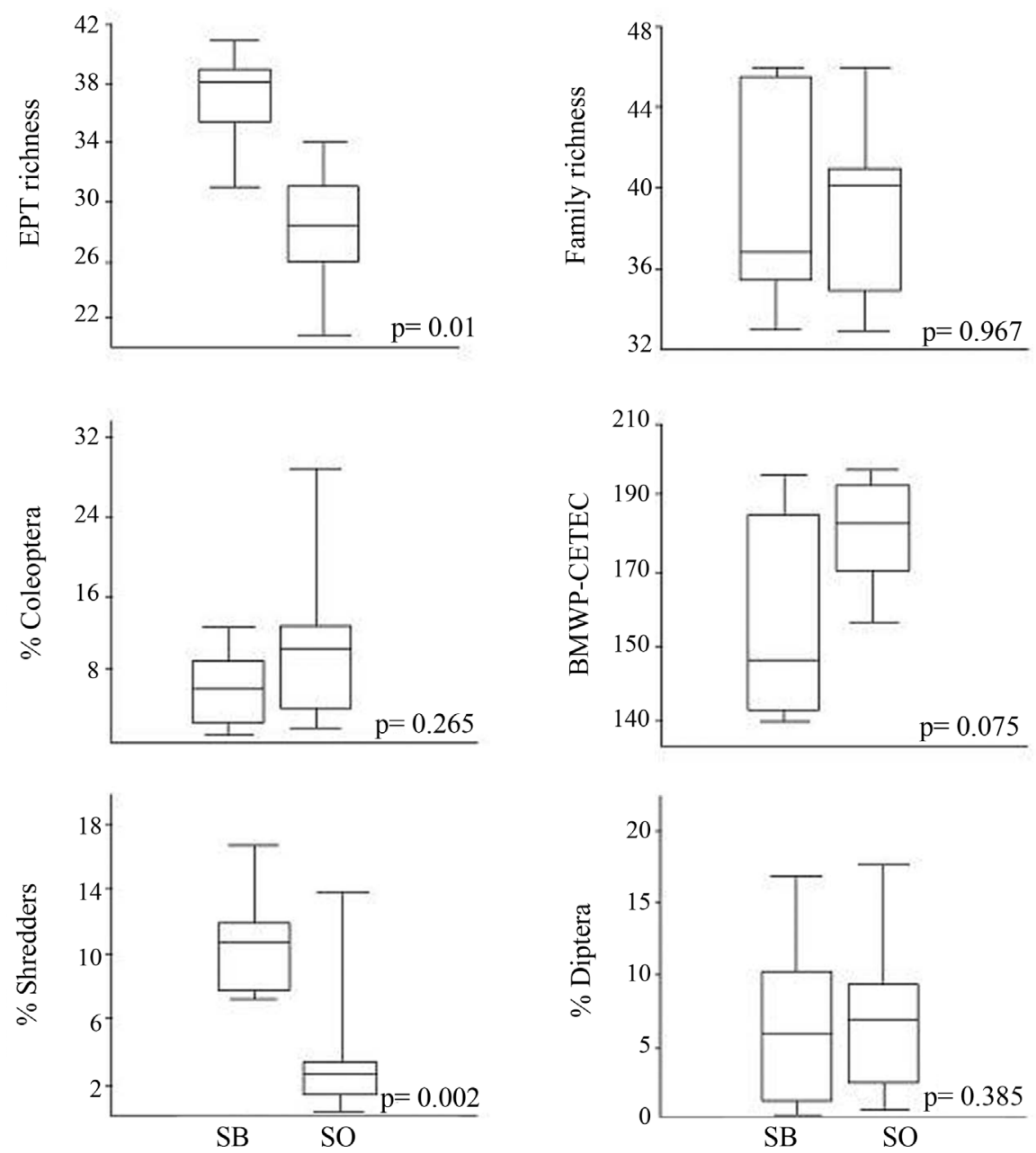

Figure 3 - Comparison of distributions of each metric composing the SOMI index for the Serra da Bocaina and Serra dos Órgãos regions. In the Box-and-Whisker plots, center lines represent the median, boxes represent the 25-75\% quartiles, and bars represent the maximum and minimum numbers. P-levels were obtained using Mann-Whitney U tests.

Plecoptera, \% Diptera, \% Coleoptera, \% Collector, \% Scraper and \% Predator. From the six metrics of the SOMI, only \% Shredder was eliminated in this step. Then, we performed redundancy tests, using Pearson correlation coefficients for metrics from the same category. As expected, Richness metrics (Total, Family, EPT, Plecoptera and Trichoptera Richness) were highly correlated. From these five metrics, we chose two metrics to integrate the MISB: the fastest/easiest to calculate, Family Richness, and one which represented the regional biodiversity (Trichoptera, at genus-level). The BMWP and the IBE-IOC indices were also correlated, and we chose the latter because it was specifically developed for the Rio de Janeiro State. The other chosen metrics (EPT / Chironomidae, \% Diptera, \% Coleoptera) had low correlations with the other three metrics and between them. In summary, after following these steps, six metrics were selected for the MISB: Family Richness, Trichoptera Richness, EPT/Chironomidae, IBE-IOC Index, \% Diptera and \% Coleoptera (Figure 4). The upper and lower thresholds were calculated for each metric, based on the distribution of values among reference or impaired sites (Table 2). The sum of scores obtained for each metric resulted in the MISB final score, which was divided in five quality classes: Severely Impaired, Impaired, Regular, Good and Excellent (Table 3).

For the test of the MISB was performed a Principal Components Analysis (PCA) on environmental variables (altitude, mean width, water temperature, $\mathrm{pH}$, Conductivity, Total-P, Total-N, NH3-N, Cl-, Total Alkalinity, \% Urban upstream area, \%Forested upstream area, mean width of riparian cover, and RCE index). The first PCA axis explained $52.8 \%$ of the variance (eigenvalue $=7.92$ ) and indicated the gradient of impairment. Highest positive loadings were related to good integrity land-use (\% Forested area, Riparian width and RCE index), while highest negative loadings indicated urbanization (\%Urban area, Total-Nitrogen and Total-Phosphorus) (Table 4). The pattern on the second axis (eigenvalue $=4.13$, $27.5 \%$ variance explained) was unclear. The first PCA 

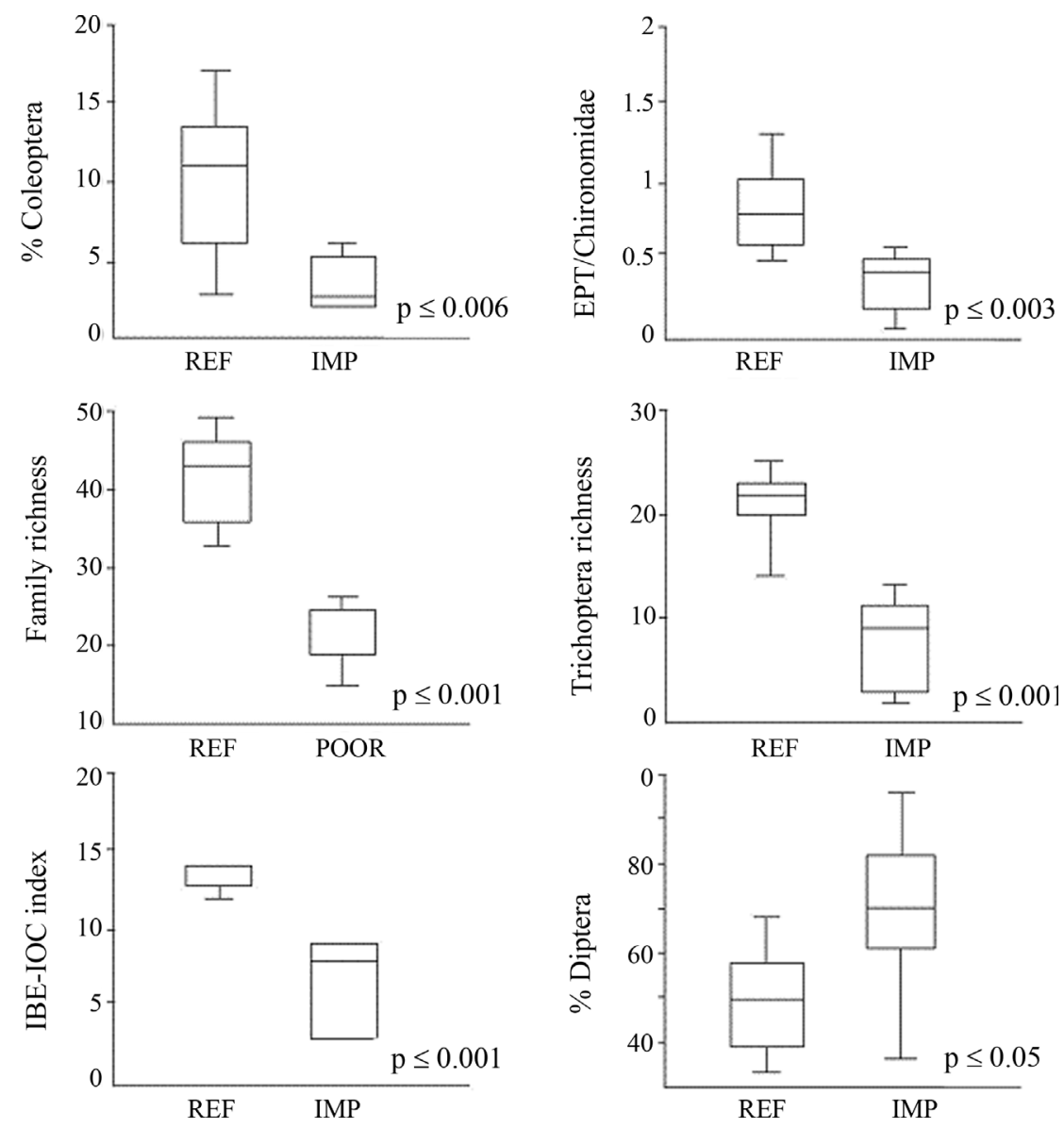

Figure 4 - Metrics comparison between Reference (REF) and Poor sites at Serra da Bocaina region. In the Box-and Whisker plots, center line represent the median, boxes represent the $25-75 \%$ quartiles, and bars represent the maximum and minimum numbers. p-levels were obtained using Mann-Whitney U tests.

Table 2 - Expected responses with increased impairment and metric value thresholds for the six metrics selected to integrate the Multimetric Index for Serra da Bocaina region (MISB).

\begin{tabular}{lll}
\hline MISB metrics & $\begin{array}{l}\text { Expected response } \\
\text { with impairment }\end{array}$ & $\begin{array}{l}\text { Metric values } \\
\text { thresholds }\end{array}$ \\
\hline Family richness & Decrease & $\begin{array}{l}\text { Upper }=46 \\
\text { Lower }=19\end{array}$ \\
$\begin{array}{l}\text { Trichoptera } \\
\text { richness }\end{array}$ & Decrease & Upper $=23$ \\
EPT/Chironomidae \\
ratio & Decrease & Lower $=4$ \\
IBE-IOC & & Upper $=1.1$ \\
& Decrease & Uower $=0.2$ \\
\% Coleoptera & Decrease & Lower $=2$ \\
& & Upper $=13$ \\
\% Diptera & Increase & Lower $=2$ \\
& & Upper $=84$ \\
\hline
\end{tabular}

Table 3 - The MISB classification system, divided in five classes of environmental stream quality.

\begin{tabular}{lc}
\hline Class & Scores \\
\hline Excellent & $80-100$ \\
Good & $60-79$ \\
Regular & $40-59$ \\
Impaired & $20-39$ \\
Severely impaired & $0-19$ \\
\hline
\end{tabular}

axis was highly correlated with MISB scores $(r=0.856$, $\mathrm{p}<0.001)$.

\section{Discussion}

Both studied regions were in the same mountain chain, same ecoregion, same vegetation dominium, at similar latitudinal and altitudinal range, and less than 300 $\mathrm{km}$ distant from each other. Based on this, we hypothesized that they would have similar faunal structure and composition at reference sites, allowing the application 
Table 4 - Factor loadings (PCA axes 1 and 2) of environmental parameters of 11 test-sites in the Serra da Bocaina region.

\begin{tabular}{lcc}
\hline Variable & PCA Axis 1 & PCA Axis 2 \\
\hline \% forested area & 0.342 & 0.024 \\
Riparian width & 0.319 & 0.165 \\
RCE index & 0.316 & -0.163 \\
Altitude & 0.253 & 0.253 \\
Dissolved oxygen & 0.169 & -0.329 \\
Total alkalinity & 0.157 & 0.376 \\
pH & 0.118 & 0.153 \\
Cl- & 0.106 & 0.416 \\
Stream width & -0.156 & -0.393 \\
Water temperature & -0.257 & -0.105 \\
Conductivity & -0.278 & -0.188 \\
NH $H_{3} \mathrm{~N}$ & -0.291 & 0.271 \\
Total-P & -0.292 & 0.273 \\
Total-N & -0.297 & 0.259 \\
\% Urbanized area & -0.335 & 0.135 \\
\hline
\end{tabular}

of the SO Multimetric Index, developed for one of those regions (Baptista et al., 2007). However, our results indicated that biologically they could be treated as two bioregions. The SB region often exhibited higher richness numbers, for all macroinvertebrate groups, but notably for Trichoptera (33 genera in SB region, 20 in SO region) and Ephemeroptera (24 genera in SB region, 16 in SO region). Although sites sampled at both regions were considered as "reference", the SB region was better preserved than SO region. Historically, the SO region was modified - logging in the last 40-y, with widespread deforestation - and then occupied by secondary vegetation, which nowadays represent reference conditions. According to Harding, et al. (1998) past land-use activity, particularly agriculture, may result in long-term modifications to and reductions in aquatic diversity, regardless of reforestation of riparian zones.

In the last two decades, many studies emphasized the need to evaluate the faunal responses to stress at different spatial scales. Some studies found stronger relationships between macroinvertebrate fauna and environmental conditions at ecoregional level (Barbour et al., 1996, Reynoldson et al., 1997, Karr and Chu. 1997). Other studies, like our own, found macroinvertebrate fauna more associated with local aquatic habitat or to land-use adjacent to the stream than with strict ecoregional classification (Waite et al., 2000, Mykrä et al., 2004, Frimpong et al., 2005, Munn et al., 2009). It is logical to suppose that these differences, if they exist, they would result in biological indices as well. Therefore, it is advisable to test, and if necessary, develop new biological indices to indicate these local/regional conditions, even if areas are in the same ecoregion. Studies in Canada and USA indicate the need to adapt or create new biological indices for bioregions within an ecoregion (Fore et al., 1994, Maxted et al., 2000, McCormick et al., 2001, Sylvestre et al., 2005).

In this study, three (of six) metrics used in the SOMI Index were chosen to integrate the MISB - Family Richness, \% Coleoptera and \% Diptera. The BMWP-CETEC index was sensitive, but was substituted by the IBE-IOC because the latter was developed for the Rio de Janeiro State. The two other metrics which integrated the MISB were EPT / Chironomidae ratio and Trichoptera Richness because they had low redundancy with other metrics and represented a relevant portion of the SB fauna. The index composition with these six metrics (Family Richness, \% Coleoptera, \% Diptera, IBE-IOC index, EPT/Chironomidae ratio and Trichoptera Richness), was the most adequate for the SB region.

A common difficulty is to establish a biological index which discerns different levels of impairment in an altitudinal gradient. Frequently, historical and current land uses differ from upland to lowland areas, and there are scarce reference sites in areas where access is easier to human populations, usually at lowlands (Klemm et al., 2003). This problem is expected to be greater when the area where the index is applied includes more than one river basin or ecoregion. In the mountainous Serra do Mar region - located along the coast of $30 \%$ of Brazil most human activities are located in lowland areas, therefore making altitude often negatively correlated with human impairment. In this study, to assure the sensitivity of the index to the measured impairment, we sampled reference and impaired sites along the altitudinal gradient and at streams with different sizes. Our results showed that the MISB was more related to land-use and water physical and chemical parameters than with altitude or stream width (Table 4). The fact that most MISB metrics are calculated using higher taxonomic levels also reduces the influence of altitude, since distribution of taxa at those levels usually occurs at broader areas and/or along the altitudinal gradient. Most metrics in the MISB require identification mostly to family-level (except for Trichoptera in genus-level). This is important for a biological index in Brazil, where identification of benthic macroinvertebrates at the species level is not yet possible due to inadequate taxonomic knowledge and lack of comprehensive taxonomic keys. It is important to notice that even in this higher level of taxonomic identification, the MISB responded well to a generalized measure of disturbance (Table 4) representing a wide variety of combined stressors, being an adequate and efficient tool for detecting environmental impacts. Our study indicated the importance of testing biological indices before using in new areas, even within the same ecoregion, and calls the attention that historical land-use should be considered as an important variable influencing indices based on macroinvertebrate assemblages. 


\section{Acknowledgments}

The authors would like to thank the financial support of CNPq (Edital CNPq/PROEP 400107/2011-2 and CT-Hidro/PDJ) and the colleagues (Valdinei Valin and Denise Borges Assunção) of the LAPSA/IOC/FIOCRUZ for the water analysis of this study.

\section{References}

ANGRISANO, EB., 1995. Insecta Trichoptera. In LOPRETTO, EC. and TELL, G. (Ed.). Ecosistemas de Aguas Continentales: Metodologia para su Estudio. La Plata: Ediciones Sur. Vol. 3, p. 1199-1224.

AYRES, M., AYRES, MJR., AYRES, DL. and SANTOS, AS. , 2000. BioEstat2.0: aplicações estatísticas nas áreas das ciências biológicas e médicas. Belém: Sociedade civil Mamirauá. p. 272.

ARMITAGE, PD., MOSS, D., WRIGHT, JF. and FURSE, MT., 1983. The performance of a new biological water quality score based on macroinvertebrates over a wide range of unpolluted running-water sites. Water Research, vol. 17, p. 333-347.

BAPTISTA, DF., BUSS, DF., DIAS, LG., NESSIMIAN, JL., DA SILVA, ER., MORAES NETO, AHA., CARVALHO, SN., OLIVEIRA, MA. and ANDRADE, LR., 2006. Functional feeding groups of Brazilian Ephemeroptera nymphs : ultrastructure of mouthparts. Annels Limnologie, vol. 42, no 2, p. 87-96.

BAPTISTA, DF., BUSS, DF., EGLER, M., GIOVANELLI, A., SILVEIRA, MP. and NESSIMIAN, JL., 2007. A multimetric index based on benthic macroinvertebrates for evaluation of Atlantic Forest sites at Rio de Janeiro State, Brazil. Hydrobiologia, vol. 575, no. 1, p. 83-94.

BAPTISTA, DF., SOUZA, RSG., VIEIRA, CA., MUGNAI, R., SOUZA, AS. and OLIVEIRA, RBS, 2011. Multimetric index for assessing ecological condition of running waters in the upper reaches of the Piabanha-Paquequer-Preto Ba$\sin$ (RJ, Brazil). Zoologia, vol. 28, no.5, p. 619-628.

BARBOUR, MT., GERRITSEN, J., SNYDER, BD. and STRIBLING, J B., 1999. Rapid Bioassessment Protocols for Use in Streams and Wadeable Rivers: Periphyton, Benthic Macroinvertebrates and Fish. 2nd Edition. Washington, DC.: Environmental Protection Agency, Office of Water.

BARBOUR, MT., GERRITSEN, J., GRIFFITH, GE., FRYDENBORG, R., MCCARRON, E., WHITE, JS. and BASTIAN, ML., 1996. A framework for biological criteria for Florida sites using benthic macroinvertebrates. Journal of the North American Benthological Society, vol.15, no2.p. 185-211.

BELLE, J., 1992. Studies on ultimate instar larvae of Neotropical Gomphidae, with the description of Tibiagomphus gen. nov. (Anisoptera). Odonatologica, vol. 21, no.3, p. $1-24$.

BLOCKSOM, KA., 2003. A performance comparison of metric scoring methods for a multimetric index for Mid-Atlantic highland streams. Environmental Management, vol. 31, no. 5 , p. 670-682.

BÖHMER, JC., RAWER, J. and ZENKER, A., 2004. Multimetric assessment of data provided by water managers from Germany: assessment of several different types of stressors with macrozoobenthos communities. Hydrobiologia, vol. 516, no.1, p. 215-228.

BUFFAGNI, A., ERBA, S., CAZZOLA, M. and KEMP, LL. 2004. The AQEM multimetric system for the southern
Italian Alpennines: assessing the impact of water quality and habitat degradation on pool macroinvertebrates in Mediterranean rivers. Hydrobiologia, vol. 516, no.1, p. 313-329.

BUSS, DF. and BORGES, EL., 2008. Application of Rapid Bioassessment Protocols (RBP) for Benthic Macroinvertebrates in Brazil: Comparison between Sampling Techniques and Mesh Sizes. Neotropical Entomology, vol. 37, no.3, p. 288-295.

BUSS, DF. and VITORINO, AS., 2010. Rapid Bioassessment Protocols using benthic macroinvertebrates in Brazil: evaluation of taxonomic sufficiency. Journal of the North American Benthological Society, vol.29, no.2, p. 562-571.

CARVALHO, AL., 1989. Description of the larvae of Neuraeschna Costalis (Burmeister), with notes on its biology, and a key to the genera of Brazilian Aeshnidae Larvae (Anisoptera). Odonatologica, vol. 18, no. 4, p. 325-332.

CARVALHO, AL. and CALIL, ER., 2000. Chaves de identificação para as famílias de Odonata (Insecta) ocorrentes no Brasil, adultos e larvas. Papéis Avulsos de Zoologia, vol. 41 , no. 15 , p. 223-241.

CARVALHO, AL., WERNECK-DE-CARVALHO, P. and CALIL, ER., 2002. Description of the larvae of two species of Dasythemis Karsch, with a key to the genera of Libellulidae occurring in the states of Rio de Janeiro and São Paulo, Brazil (Anisoptera). Odonatologica, vol. 31, no. 1, p. 23-33.

COUCEIRO, SRM., HAMADA, N., FORSBERG, BR., PIMENTEL, TP., and LUZ DA, SLB., 2012. Macroinvertebrate multimetric index to evaluate the biological condition of streams in the Central Amazon region of Brazil. Ecological Indicators, vol. 18, no. 1, p. 118-125.

CETESB, 2002. Relatório de qualidade das águas interiores do Estado de São Paulo. p. 274 (Série Relatórios). Available from: http://www.cetesb.sp.gov.br/publicacoes/ publicacoes. asp.

DA SILVA, ER., SALLES, FF., NESSIMIAN, JL. and COELHO, LBN., 2003. A identificação das famílias de Ephemeroptera (Insecta) ocorrentes no Estado do Rio de Janeiro: Chave pictórica para as ninfas. Boletim do Museu Nacional de Zoologia, vol. 508, no.1, p. 1-6.

EC - EUROPEAN COMMISSION, 2000. Directive 2000/60/EC of the European Parliament and Council, establishing a framework for Community action in the field of water policy Official, Journal of the Europea Cотmunity, vol. 327, no.1, p. 1-72.

FERREIRA, WR., PAIVA, LT. and CALLISTO, M., 2011. Development of a benthic multimetric index for biomonitoring of a Neotropical watershed. Brazilian Journal of Biology, vol. 71, no.1, p.15-25.

FREY, G., 1977. The integrity of water. Washington, DC.: USEPA, BALLENTINE and GUARRIA. p. 127-140.

FRIMPONG, EA., SUTTON, TM., ENGEL, BA. and SIMON, TP., 2005. Spatial-Scale effects on Relative Importance of Physical Habitat predictors of Stream Health. Environmental Management, vol. 36, no. 6, p. 899-917.

FEEMA, 1979. Fundação Estadual de Engenharia do Meio Ambiente. Métodos de análise fisico-química da água. Rio de Janeiro, DICOMT. vol. 3.

FORE, LS., KARR, JR. and CONQUEST, LL., 1994. Statistical properties of an index of biotic integrity used to evaluate water resources. Canadian Journal of the Fisheries and Aquatic Sciences, vol. 51, p. 1077-1087.

GANASAN, V. and HUGHES, RM,. 1998. Application of an index of biological integrity (IBI) to fish assemblages of 
the rivers Khan and Kshipra (Madhya Pradesh), India. Freshwater Biology, vol. 40, no.1, p. 367-383.

GABRIELS, W., LOCK, K., De PAUW, N. and GOETHALS, PLM., 2010. Multimetric Macroinvertebrate Index Flanders (MMIF) for biological assessment of rivers and lakes in Flanders (Belgium). Limnologica, vol. 40, no. 3, p. $199-207$.

GHETTI, PF., 1997. Indice Biotico Esteso (IBE). I Macroinvertebrati nel Controllo della Qualita degli Ambienti di Acque Correnti. Trento: Agenzia provinciale per la protezione dell'ambiente. $222 \mathrm{p}$.

GIBSON, GR., BARBOUR, MT., STRIBLING, JB., GERRITSEN, J. and KARR, JR., 1996. Biological Criteria. Technical Guidance for Sites and Small Rivers. Washington, DC.: Environmental Protection Agency, Office of Science and Technology.

GUIMARÃES, AE., GENTILE, C., LOPES, CM., SANT'ANNA, A. and JOVITA, AM., 2000. Ecologia de mosquitos (Diptera: Culicidae) em áreas do Parque Nacional da Serra da Bocaina, Brasil. I - Distribuição por hábitat. Revista de Saúde Pública, vol. 34, no. 3, p. 243-250.

HAMMER, Ø., HARPER, DAT. and RYAN, PD., 2001. PAST: Paleontological Statistics Software Package for Education and Data Analysis. Palaeontologia Electronica. Available from: http://palaeo-electronica.org/2001_1/ past/issue1_01.htm .

HARDING, JS., BENFIELD, EF., BOLSTAD, PV., HELFMAN, GS. and JONES, EBD., 1998. Stream biodiversity: The ghost of land use past. Proceedigings of the National Academy of Science, vol. 95, p. 14843-14847.

HERING, D., VERDONSCHOT, PFM., MOOG, O. and SANDIN, L., 2004. Overview and application of the AQEM assessment system: Integrated Assessment of Running Waters in Europe. Hydrobiologia, vol. 516, no.1, p. $1-20$.

HILSENHOFF, WL., 1987. An improved biotic index of organic stream pollution. Great Lakes Entomology, vol. 20, no.1, p. 31-39.

HILSENHOFF, W. L., 1988. Rapid field assessment of organic pollution with a family-level biotic index. Journal of the North American Benthological Society, vol.7, no. 1, p. 65-68.

HUGHES, RM., KAUFMANN, PR., HERLIHY, AT., KINCAID, TM., REYNOLDS, L. and LARSEN. DP., 1998. A process for developing and evaluating indices of fish assemblages integrity. Canadian Journal of the Fisheries and Aquatic Sciences, vol. 55, p. 1618-1631.

JOHNSON, RK., WIEDERHOLM, T. and ROSENBERG, DM., 1993. Freshwater biomonitoring using individual organisms. Populations and species assemblages of benthic Macroinvertebrates. In ROSENBERG, DM. and RESH, VH., (Eds.) Freshwater biomonitoring and benthic macroinvertebrates. New York: Chapman \& Hall. $488 \mathrm{p}$.

JUNQUEIRA, VM. and CAMPOS, SCM., 1998. Adaptation of the "BMWP" Method for Water Evaluation to Rio das Velhas Watershed (Minas Gerais, Brazil). Acta Limnológica Brasiliensia, vol. 10, no.2, p. 125-135.

KARR, JR., 1991. Biological integrity: a long-neglected aspect of water resource management. Ecological Application, vol. 1, p. 66-84

KARR, JR. and CHU, EW., 1997. Biological monitoring and assessment: Using multimetric index effectively. Seattle: University of Washington.
KARR, JR. and DUDLEY, DR., 1981. Ecological perspective on water quality goals. Environmental Management, vol. 5, no.1, p. 55-68.

KARR, JR., FAUSCH, KD., ANGERMEIER, PL., YANT, PR. and SCHLOSSER, IJ., 1986. Assessment of biological integrity in running water: a method and its rationale. Illinois: Illinois Natural History Survey. 28 p. Special Publication, no. 5 .

KING, RS. and RICHARDSON, CJ., 2003. Integrating Bioassessment and Ecological Risk assessment: An Approach to Developing Numerical Water-Quality Criteria. Environmental Management, vol. 31, no. 6, p. 795-809.

KLEMM, DJ., BLOCKSOM, KA., FULK, FA., HERLIHY, AT., HUGHES, RM., KAUFMANN, PR., PECK, DV., STODDARDS, JL., THOENY, WT., GRIFFITH, MB. and DAVIS, WS., 2003. Development and evaluation of a macroinvertebrates biotic integrity (MBII) for regionally assessing Mid-Atlantic Highlands Streams. Environmental Management, vol. 31, no. 5, p. 656-669.

KOLKWITZ, R., and MARSSON, M., 1909. Ökologie der tierischen Saprobien. Beiträge zur Lehre von des biologischen Gewasserbeurteilung. Internationale Revue der gesamten Hydrobiologie und Hydrographie, vol. 2, no. 1, p. 126-152.

MAXTED, JD., BARBOUR, M.T., GERRITSEN, J., PORETTI, V., PRIMROSE, N., SILVIA, A., PENROSE, D. and RENFRON, R., 2000. Assessment framework for midAtlantic coastal plain sites using benthic macroinvertebrates. Journal of the North American Benthological Society, vol. 19, no.1, p. 128-144.

MORENO, P., FRANÇA, JF., FERREIRA, WR., PAZ, AD., MONTEIRO, MI. and CALLISTO, M., 2009. Use of the BEST model for biomonitoring water quality in Neotropical basin. Hydrobiologia, vol. 630, no. 1, p. 231-242.

MCCORMICK, FH., HUGHES, RM., KAUFMANN, PR., PECK, DV., STODDARD, JL. and HERLIHY, AT., 2001. Development of an index of biotic integrity for the mid-Atlantic highlands region. Transactions of the American Fisheries Society, vol. 130, p. 857-877.

MERRITT, RW. and CUMMINS, KW., 1996. An introduction to the Aquatic Insects of North America. 3rd Edition. Dubuque, Iowa : Kendall/Hunt. 862 p.

METCALFE, JL., 1989. Biological Water Quality Assessment of Running Waters Based on Macroinvertebrate Communities: History and Present Status in Europe. Environmental Pollution, vol. 60, no.1, p. 101-139.

MINNS, CK., CAIRNS, VW., RANDALL, RG. and MOORE, JE., 1994. An Index of Biotic Integrity (IBI) for fish assemblages in littoral zone of Great Lakes areas of concern. Canadian Journal of Fisheries and Aquatic Sciences, vol. 51, p. 1804-1822.

MMA/SBF. 2000. Avaliação e ações prioritárias para a conservação da biodiversidade da Mata Atlântica e Campos Sulinos. Brasília: Conservation International do Brasil, Fundação SOS Mata Atlântica, Fundação Biodiversitas, Instituto de Pesquisas Ecológicas, Secretaria do Meio Ambiente do Estado de São Paulo, SEMAD/Instituto Estadual de Florestas-MG. 40 p.

MUGNAI, R., OLIVEIRA, RB., CARVALHO, LC. and BAPTISTA, DF., 2008. Adaptation of the Indice Biotico Esteso (IBE) for water quality. Tropical Zoology, vol. 21, no. 1, p. 57-74.

MUNN, MD., WAITE, RI., LARSEN, DP. and HERLIHY, AT., 2009. The relative influence of geographic location and reach-scale habitat on benthic invertebrate assem- 
blages in six ecoregions. Environmental Monitoring Assessement, vol. 154, no. 1, p. 1-14.

MYKRÄ, H., HEINO J, and MUOTKA, T., 2004. Variability of Lotic Macroinvertebrate Assemblages and Stream Habitat Characteristics Across Hierarchical Landscape Classifications. Environmental Management, vol. 34, no.3. p. 341-352.

NIESER, N., and de MELO, AL., 1997. Os heterópteros aquáticos de Minas Gerais, guia introdutório com chave de identificação para as espécies de Nepomorpha e Gerromorpha. Belo Horizonte: Editora UFMG. 180 p.

OLIVEIRA, RBS., BAPTISTA, DF., MUGNAI, R., CASTRO, CM., HUGHES, RM. 2011. Towards rapid bioassessment of wadeable streams in Brazil: Development of the Guapiacu-Macacu Multimetric Index (GMMI) based on benthic macroinvertebrates. Ecological Indicators, vol. 11. p. $1584-1593$.

OLIFIERS, MH., DORVILLÉ, LFM., NESSIMIAN, JL., and HAMADA, N., 2004. A key to Brazilian genera of Plecoptera (Insecta) based on nymphs. Zootaxa, vol. 651. no.1, p. 1-15.

PASSOS, MIS., NESSIMIAN, JL. and FERREIRA-JR, N., 2007. Chaves para identificação dos gêneros de Elmidae (Coleoptera) ocorrentes no Estado do Rio de Janeiro, Brasil. Revista Brasileira de Entomologia, vol. 51, no. 1, p. $42-53$.

PETERSEN, RC., 1992. The RCE: a Riparian, channel and environmental inventory for small sites in the agricultural landscape. Freshwater Biology, vol. 27, no. 1, p. 295-306.

PINTO, P., ROSADO, J., MORAIS, M. and ANTUNES, I., 2004. Assessment methodology for southern siliceous basins in Portugal. Hydrobiologia, vol. 516, no.1, p. 193216.

PLAFKIN, JL., BARBOUR, MT., PORTER, KD., GROSS, SK. and HUGHES, RM., 1989. Rapid bioassessment protocols for use in sites and rivers: Benthic macroivertebrates and fish. Washington, DC: US Environmental Protection Agency.

REYNOLDSON, TB., NORRIS, RH., RESH, VH., DAY, KE. and ROSEMBERG, DM., 1997. The reference condition: a comparison of multimetric and multivariate approaches to assess water-quality impairment using benthic macroinvertebrates. Journal of the North American Benthological Society, vol.16, 833-852.

SALLES, FF., DA SILVA, ER., SERRÃO, JE. and FRANCISCHETTI, CN., 2004. Baetidae (Ephemeroptera) na Região Sudeste do Brasil: Novos registros e chave para os gêneros no estágio ninfal. Neotropical Entomology, vol. 33 , no. 5 , p. $725-735$.

SYLVESTRE, S., FLUEGEL, M. and TUOMINEN, T., 2005. Benthic invertebrate assessment of sites in the Georgia Basin using the least-disturbed condition approach: expansion of the Fraser River invertebrate monitoring program 1998-2002. Vancouver: Environment Canada. $194 \mathrm{p}$.

VLEK, HE., VERDONSCHOT, PFM. and NIJBOER, RC., 2004. Toward a multimetric index for the assessment of Dutch sites using benthic macroinvertebrate. Hydrobiologia, vol. 516, no. 1, p. 173-189.

WAITE, IR., HERLIHY, AT., LARSEN, DP. and KLEMM, DL., 2000. Comparing strengths of geographic and nongeographic classications of stream benthic macroinvertebrates in the Mid-Atlantic Highlands, USA. Journal of the North American Benthological Society, vol. 19, p. 429-441.

WINGET, RN. and MANGUM, FA., 1979. Biotic Condition Index: integrated biological, physical, and chemical stream parameters for management. Ogden: US. Forest Service Intermountain Region, US. Department of Agriculture. $51 \mathrm{p}$.

WIGGINS, GB., 1996. Larvae of the North American Caddisfly Genera (Trichoptera). 2nd ed. Toronto: University of Toronto Press. 457 p. 